\title{
Money Damages and Corrective Advertising: An Economic Analysis
}

\author{
Paul Heald $\dagger$
}

In unfair competition cases, injunctive relief is the norm ${ }^{1}$ for three reasons. First, it is difficult to prove and then calculate actual damages. Second, an injunction alone usually provides substantial relief. ${ }^{2}$ Third, the substantive law of damages in the field of unfair competition $^{3}$ is uncertain and unstable. One commentator on the Lanham Act notes that, when courts grant money damages, the "confluence of evidentiary complexity and legal confusion has resulted in some plaintiffs receiving windfall recoveries while others find injuries uncompensated; meanwhile, defendants face uncertain liability and capricious penalties." This instability in the law has led to diverse attempts to address the damage issue.

Perhaps the most troubling development in the search for an accurate, consistent rationale for awarding money damages in unfair competition cases has been the federal courts' adaptation of the Federal Trade Commission's ("FTC") injunctive remedy of corrective advertising. Federal courts have applied this rationale-usually used to justify corrective advertising injunctions-to

$\dagger$ A.B. 1980, University of Illinois; A.M. 1982, University of Illinois; J.D. Candidate 1988, The University of Chicago.

1 J. Thomas McCarthy, 2 Trademarks and Unfair Competition 495 (2d ed. 1984); Edward J. Kessler and Robert W. Sacoff, Products of the Mind: Proving Damages in Intellectual Property Cases, 20 Trial 40, 42 (July 1984).

2 Champion Plug Co. v. Sanders, 331 U.S. 125, 131 (1947) (accounting of defendant's profits denied "where an injunction will satisfy the equities of the case"). See also Foxtrap, Inc. v. Foxtrap, Inc., 671 F.2d 636, 641-42 (D.C.Cir. 1982).

s This comment refers to "unfair competition" as the species of business tort encompassing the infringement of trademarks, trade names, trade dress, trade symbols, service marks, product designs, packaging, and the like. Other torts such as monopolization, interference, or price fixing, often included under the rubric "unfair competition," may raise different issues and will not be discussed except when analogy is helpful.

15 U.S.C. § 1051 et seq. (Supp. 1985). The Lanham Act provides for the registration and regulation of trademarks used in interstate commerce.

- James M. Koelemay, Jr., Monetary Relief for Trademark Infringement Under the Lanham Act, 72 T.M.R. 458, 458 (1982). Koelemay's article is the most extensive recent discussion of damages in trademark and unfair competition cases. 
damage actions arising under the Lanham Act and common law. ${ }^{6}$ The federal courts' version of corrective advertising uses the defendant's advertising expenditures as a measure of money damages. The court makes this award without requiring the plaintiff to quantify his actual damages. ${ }^{7}$

Although neither judicial opinions nor the academic literature have examined the validity of this relief in depth, courts have used the corrective advertising injunction rationale to justify two of the largest damage awards in the history of trademark law. ${ }^{8}$ Money damage awards for corrective advertising are not always of momentous proportions, ${ }^{9}$ but the fear that courts will base damages on often substantial advertising budgets adds a new and controversial factor which companies must consider in product marketing and litigation decisions.

This comment demonstrates that corrective advertising damage awards are unjustified because they miscompensate plaintiffs, cause undesirable market behavior, and impose needless costs on businesses and consumers. Part I of the comment examines how the federal courts adopted the corrective advertising measure of damages as an attempt to compensate plaintiffs for lost good will. Part II explores the arbitrary and unprecedented nature of the awards. Part III acknowledges the need to compensate for damage to good will, but explains in economic terms how the corrective advertising damage awards result in an inefficient level of deterrence and impose excessive social costs. Part IV sets forth alternative accounting methods which more precisely measure damage to good will.

- See Big O Tire Dealers, Inc. v. Goodyear Tire and Rubber, 408 F.Supp. 1219 (D.Colo. 1976), aff'd as modified 561 F.2d 1365 (10th Cir. 1977).

${ }^{7}$ See McCarthy, 2 Trademarks at 512 (cited in note 1). See also J. Thomas McCarthy, Important Trends in Trademark and Unfair Competition Law during the Decade of the 1970's, 71 T.M.R. 93, 107-112 (1981). This comment uses the term "corrective advertising" to describe damage awards based on the actual amount spent by the defendant on advertising or on the amount a court speculates a plaintiff would have to spend to "counteract" a defendant's advertising.

B See U-Haul Intern., Inc. v. Jartran, Inc., 793 F.2d 1034, 1037 (9th Cir. 1986) (\$6 million of award based on the defendant's advertising expenditures); Big O, 561 F.2d at 1375 (\$678,302 award based on 25 percent of defendant's advertising costs).

- West Des Moines State Bank v. Hawkeye Bancorp., 722 F.2d 411, 412 (8th Cir. 1983) (\$18,876); Durbin Brass Works, Inc. v. Schuler, 532 F.Supp. 41, 44 (E.D.Mo. 1982) (\$10,000); Hain Pure Food Co., Inc. v. Sona Food Products Co., 491 F.Supp. 39, 41 (C.D.Cal. 1980) $(\$ 1,000)$. 


\section{The Emergence of Corrective Advertising}

\section{A. Money Damages and Unfair Competition}

In the typical unfair competition case, the plaintiff brings a motion for a preliminary injunction, claiming that the defendant infringed rights established in the plaintiff's product or trademark. Upon a showing that a likelihood of confusion exists between the products or trademarks in question, and subject to the particular equitable balancing used in the jurisdiction, the plaintiff almost certainly will be entitled to an injunction. ${ }^{10}$ Actual confusion need not be proven. ${ }^{11}$ At this point, litigants settle most cases out of court. Because the disposition of the motion for a preliminary injunction effectively decides the most important issue in the case-likelihood of success on the merits-further litigation is usually unnecessary. Plaintiffs seldom pursue a trial through the damage phase because it is expensive, and because the court's preliminary injunction decision usually gives plaintiffs a good idea of what amount of damages they might expect. Thus, it is more efficient for plaintiffs to pursue damage awards through settlement negotiations than through trial.

Plaintiffs who pursue money damages at trial face uncertainty among "the hodgepodge and confusion in judge-made rules of recovery."12 At least four different bases exist on which to award compensatory damages:

(1) profits lost by plaintiff due to infringement;

(2) actual business losses caused by the infringement other than lost profits;

(3) defendant's profits as an estimate of plaintiff's lost profits; or

(4) defendant's profits on an unjust enrichment theory..$^{13}$

${ }^{10}$ See Processed Plastic Co. v. Warner Communications, Inc., 675 F.2d 852, 858 (7th Cir. 1982) (trademark infringement presumptively occasions irreparable harm).

"See cases collected in McCarthy, 2 Trademarks at 50-55 (cited in note 1) (likelihood of confusion presumptively results in irreparable harm).

${ }^{12}$ Koelemay, 72 T.M.R. at 525 (cited in note 5). See also Burndy Corp. v. Teledyne Industries, Inc., 748 F.2d 767, 771-73 (2d Cir. 1984) (discussion of damage approaches).

13 McCarthy, 2 Trademarks at 494 (cited in note 1). These measures are used under both common law and the Lanham Act which specifically provides that:

$[w]$ hen a violation of any right of the registrant of a mark registered in the Patent and

Trademark Office shall have been established ... the plaintiff shall be entitled,.... subject to the principles of equity, to recover (1) defendant's profits, (2) any damages sustained by the plaintiff, and (3) the costs of the action.

15 U.S.C. $\$ 1117$ (emphasis added). 
However, the abstract nature of trademark rights causes difficulty in proving causation and calculating damages.

Recent cases illustrate the evidentiary hurdles which block the path of would-be claimants. Courts have required proof of actual confusion, ${ }^{14}$ bad faith or intent, ${ }^{15}$ and damage to reputation; ${ }^{16}$ in addition, courts have denied damages in the absence of direct competition. ${ }^{17}$ Courts, however, are not hostile in principle to the idea of damages; they simply are reluctant to quantify them on speculative or uncertain grounds. ${ }^{18}$ Courts have fashioned these evidentiary rules in order to ensure that only concrete damages are compensated. For example, courts applying the rule that they will not award damages in the absence of competition do not deny that damage may have occurred; rather, they find that the quantification of damages is overly speculative absent competition. This may explain partially the appeal of basing a damage award on the defendant's advertising expenditures: the court can easily calculate the award and the award bears some relation to the damage done through customer confusion to the plaintiff's reputation. ${ }^{19}$

\section{B. Corrective Advertising Outside the FTC}

Federal courts have applied corrective advertising damages in unfair competition cases in two ways. First, courts sometimes have been willing to award money damages equivalent to the amount actually spent by the plaintiff to counteract the defendant's advertising. ${ }^{20}$.Thus, in Cuisinarts, Inc. v. Robot-Coupe Intern. Corp. ${ }^{21}$ the court held that the plaintiff could recover as damages any 1980).

14 Perfect Fit Industries., Inc. v. Acme Quilting Co., Inc., 618 F.2d 950, 955 (2d Cir.

15 Aris-Isotoner Gloves, Inc. v. Fownes Bros. \& Co., 594 F.Supp. 15, 25 (S.D.N.Y. 1983).

${ }_{16}$ St. Charles Mfg. Co. v. Mercer, 737 F.2d 891, 893 (11th Cir. 1983).

${ }^{17}$ Raxton Corp. v. Anania Associates, Inc., 668 F.2d 622, 625 (1st Cir. 1982).

${ }^{18}$ Foxtrap, 671 F.2d at 641-42 ("If the district court's award was to compensate plaintiff for its losses, there is no adequate record support for the dollar amount."); Raxton, 668 F.2d at 625 .

18 The court in Big O, 408 F.Supp. at 1232, held

[t]hat confusion is, in itself, damage. The appearance of dishonesty and wrongful conduct by $\mathrm{Big} \mathrm{O}$ harms its reputation within the trade and with the public. It is reasonable to redress that wrong by giving the plaintiff enough money to conduct an advertising program of its own.

${ }^{20}$ Cuisinarts, Inc. v. Robot-Coupe Intern. Corp., 580 F.Supp. 634, 641 (S.D.N.Y. 1984). See also Obear-Nester Glass Co. v. United Drug Co., 149 F.2d 671, 674 (8th Cir. 1945); Taussig v. Wellington Fund, Inc., 187 F.Supp. 179, $221-22$ (D.Del. 1960), aff'd 313 F.2d 472 (3d Cir. 1963); Century Distilling Co. v. Continental Distilling Corp., 86 F.Supp. 503, 505506 (E.D.Pa. 1949), aff'd 205 F.2d 140 (3d Cir. 1953).

${ }^{21} 580$ F.Supp. 634 (S.D.N.Y. 1984). 
money it had spent on "reparative advertising" to correct false impressions created by the defendant. ${ }^{22}$ This approach has not generated much criticism. Under the Lanham Act, actual costs incurred by victims of infringement usually are recoverable. ${ }^{23}$ Although courts should make available the defense that the counter-advertising performed was unreasonable or wasteful, most courts are willing to accept counter-advertising costs as recoverable business losses. A victim of infringement is well situated to evaluate exactly how his business is being affected by unfair competition; a rule which allows recovery of pre-judgment counter-advertising expenditures provides few incentives for plaintiffs to over-advertise and seldom overcompensates because the award is never greater than the actual amount spent by the plaintiff. ${ }^{24}$

This comment is more concerned with the second form in which federal courts have adapted the FTC's corrective advertising injunction remedy. Some courts permit damages based on the advertising expenditures of the defendant, not the actual cost, if any, of counter-advertising actually done by the plaintiff. ${ }^{25}$ These damage awards warrant careful scrutiny.

Big O Tire Dealers, Inc. v. Goodyear Tire and Rubber is the seminal case in this area. ${ }^{28} \mathrm{Big} O$ involved Goodyear's marketing of a radial tire advertised as "BIGFOOT." Goodyear spent $\$ 10$ million advertising the tire nationwide although it had prior knowledge of a "BIG FOOT" bias-ply tire being sold by Big O Tire Dealers, an association of independent dealers operating in fourteen states. The jury awarded Big $\mathrm{O} \$ 2.8$ million in compensatory damages and $\$ 16.8$ million in punitive damages. ${ }^{27}$ The district court affirmed the award of $\$ 2.8$ million on a corrective advertising theory, in spite of its explicit finding that:

there is no evidence that any direct economic losses resulted. The plaintiff did not produce evidence of lost sales of Big $\mathrm{O}$ tires or any other type of lost income. Moreover, the evidence is clear that no dealers were lost and, indeed, new dealers

22 Id. at 641 .

${ }^{23}$ See 15 U.S.C. $\$ 1117$ ("any damages sustained by plaintiff" are recoverable) (emphasis added).

${ }^{24}$ A plaintiff might perform in bad faith an excessive amount of advertising, but the uncertainty of winning a subsequent suit usually should diminish this possibility. However, a defense of inefficient advertising always should be available.

${ }^{25}$ See cases cited in notes 8 and 9. See also Avis Rent A Car System, Inc. v. Hertz Corp., 223 U.S.P.Q. 1255, 1256, 226 U.S.P.Q. 95, 96 (E.D.N.Y. 1985).

${ }^{28} 408$ F.Supp. 1219 (D.Colo. 1976), aff'd as modified, 561 F.2d 1365 (10th Cir. 1977).

${ }^{27}$ This amount was reduced to $\$ 678,000$ and $\$ 4$ million on appeal. $561 \mathrm{~F} .2 \mathrm{~d}$ at $1375-76$. 
were added to the organization during the time of this concurrent use. ${ }^{28}$

The court held that "[t]he damages awarded by the jury would enable Big $\mathrm{O}$ to do an equivalent volume of advertising in the states in which there are Big $\mathrm{O}$ dealers ... [T] [Te fact of damage has been established with reasonable certainty. There is no doubt that Big O's trademark was affected by Goodyear's $\$ 10,000,000$ advertising program."

Following Big $O$, the Eighth Circuit affirmed a similar award in West Des Moines State Bank v. Hawkeye Bancorp." ("West Bank"). Affirming a finding that the defendant's use of its trade name "West Bank" infringed plaintiff's trademark rights, the Eighth Circuit found that the district court properly awarded damages based on 25 percent of the defendant's advertising expenditures. ${ }^{31}$ The court awarded this amount despite the lack of evidence of quantifiable damage to the plaintiff. It noted:

[defendant] argues that a damage award for corrective advertising is not permitted under applicable federal or state statutes. Simply put, the law does not have a remedy for a business whose trade name has been diluted, absent evidence of actual dollar loss to the plaintiff or actual dollar gain to the defendant. We do not agree. ${ }^{32}$

Convinced that infringement had harmed the plaintiff's trade name, the court refused to let uncertainty bar an award.

More recently, in U-Haul Intern. Inc. $v$. Jartran, Inc. ${ }^{33}$ the Ninth Circuit affirmed a $\$ 40$ million judgment against a truck rental company guilty of Lanham Act and common law violations. After finding liability for misleading and deceptive use of U-Haul's trademark, the district court calculated damages as follows: $\$ 6$ million based on Jartran's advertising expenditures plus $\$ 13.6$ million based on U-Haul's actual counter-advertising expenses. The court

${ }^{28} 408$ F.Supp. at 1230 . The $\$ 2.8$ million figure was arrived at because Big $O$ operated in 14 states, 28 percent of the 50 states in which Goodyear spent its $\$ 10$ million in advertising. Id. at 1231.

${ }^{29}$ Id. at 1232-33 (original emphasis). The court acknowledged the "fact of damage" in spite of the lack of evidence of direct economic loss on the theory that confusion presumptively causes damage to a trademark's good will.

30 722 F.2d 411 (1983).

${ }^{31}$ Id. at 414 . The court remanded, however, for recalculation of the base amount from which the 25 percent was to be derived because it found that not all of the defendant's advertising materials-for example, undistributed stationery-actually reached the public.

s2 Id. at 413.

ss 793 F.2d 1034 (9th Cir. 1986). 
then doubled these amounts under 15 U.S.C. $\S 1117^{\text {s4 }}$ to produce a total award of $\$ 40$ million. ${ }^{35}$ The case is especially striking because the court explicitly found the corrective advertising damage award to be authorized by federal law. Previous courts, although finding Lanham Act violations, had been hesitant to justify the corrective advertising damage award under federal law. ${ }^{36}$ Given that most unfair competition cases are decided under the Lanham Act, the case's precedential value is potentially great.

\section{Corrective Advertising and the FTC}

Since 1969, the FTC on occasion has required parties guilty of deceptive advertising not only to cease and desist from the original deceptive advertisements, but affirmatively to disseminate new advertisements designed to correct consumer impressions left by the original misleading claims. ${ }^{37}$ The FTC's authority under 15 U.S.C. $\S 45$ to order remedial advertising was challenged and approved in Warner-Lambert Co. v. F.T.C.. ${ }^{38}$ There, the court affirmed an FTC order requiring the makers of Listerine to disclose in future advertisements that "Listerine will not help prevent colds or sore throats or lessen their severity."39 The FTC had found that Listerine did not reduce the risk of illness, and that the mere cessation of claims that it did were inadequate to correct consumer misperceptions. Since Warner-Lambert, several courts have upheld the FTC's power to order corrective advertising. ${ }^{40}$

s4 Under $\$ 1117$, the court has the discretion in exceptional cases to increase damages up to an amount treble the actual damages.

38793 F.2d at 1041-42.

36 West Bank, 722 F.2d at 413-14 (Iowa law). Big O, 408 F.Supp. at 1233 (Colorado law). Because the legislative history of the Lanham Act is unclear as to whether increased damages are always available, a court as a practical matter can insulate itself from review by basing its award on state law.

${ }^{37}$ See In the Matter of Campbell Soup Co., 77 F.T.C. 664, 668 (1970); Case Comment, Warner-Lambert Co. v. F.T.C.: The Possibilities and Limitations of Corrective Advertising, 13 New Eng.L.Rev. 348 (1977); Comment, Corrective Advertising-The New Response to Consumer Deception, 72 Colum.L.Rev. 415 (1972); Richard S. Cornfeld, A New Approach to an Old Remedy: Corrective Advertising and the Federal Trade Commission, 61 Iowa L.Rev. 693 (1976); Gerald S. Thain, Corrective Advertising: The Theory and Cases, 19 N.Y.L. Forum 1 (1973); Annotation, Power of Federal Trade Commission to Issue Order Requiring Corrective Advertising, 46 A.L.R.Fed. 905 (1980).

${ }^{38} 562$ F.2d 749 (D.C.Cir. 1977).

so Id. at 752.

${ }^{10}$ See Grolier Inc. v. F.T.C., 699 F.2d 983, 988 (9th Cir. 1983); Encyclopaedia Britannica, Inc. v. F.T.C., 605 F.2d 964, 970-71 (7th Cir. 1979); Amrep Corp. v. F.T.C., 768 F.2d 1171, 1180 (10th Cir. 1985). Although in all three cases the FTC's orders were directed at personal representations made by salespeople, these courts approved of "corrective advertising." 
In Warner-Lambert, the court affirmed an FTC order that the corrective statement be made accompanying the next $\$ 10$ million worth of advertising spent to promote Listerine, to make up for almost 100 years of deceptive advertising. ${ }^{41}$ On other occasions, the FTC has required that the defendant spend an amount equal to 25 percent of the money expended in making the deceptive statements, reasoning that less money is necessary to engage the public's attention where a retraction is being made. ${ }^{42}$ However, the real cost to an FTC defendant is far less than 25 percent of its advertising budget because the FTC does not require that the defendant make the retraction in isolation. FTC defendants merely must add the FTC required language to their normal advertising. The defendant need not waste money on new unbudgeted advertising; it need only add the corrective phrasing to advertising it already would have performed. ${ }^{43}$

Thus, the federal courts' version of corrective advertising is far more costly to defendants than the remedy as applied by the FTC. The FTC relief is purely injunctive, forcing deceptive advertisers to include affirmative disclaimers in the normal course of their advertising campaigns. When the FTC uses a figure of 25 percent of the defendant's advertising budget, that sum does not impose a direct loss on the defendant, unlike the federal court remedy which entails a transfer payment of 25 percent of the defendant's advertising expenditures. The FTC frequently declines to order corrective advertising injunctions. Its standard for using such injunctions, approved as "entirely reasonable" in Warner-Lambert, is that:

[i]f a deceptive advertisment has played a substantial role in creating or reinforcing in the public's mind a false and material belief which lives on after the false advertising ceases, there is clear and continuing injury to competition and to the consuming public as consumers continue to make purchasing decisions based on the false belief. Since this injury cannot be averted by merely requiring respondent to cease disseminating the advertisement, we may appropriately order respon-

12562 F.2d at 762-64.

${ }^{42}$ Amstar Corp., Trade Reg.Rep. (CCH) II 20,356 at 20,240 (F.T.C. 1973); American Home Prod. Corp., Trade Reg.Rep. (CCH) II 19,962 at 21,984 (F.T.C. 1972); Sun Oil Co.,

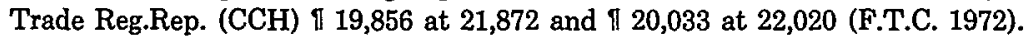

${ }^{43}$ So, if a marketer of a cure for baldness spends $\$ 1$ million on advertisements which contain false statements, the FTC may require that retractions accompany the next $\$ 250,000$ of advertisements the defendant buys. 
dent to take affirmative action designed to terminate the otherwise continuing ill effects of the advertisement. ${ }^{44}$

The remedy of a corrective advertising injunction, as imposed by the FTC, may seem "entirely reasonable" to the federal courts, ${ }^{45}$ but it is hardly uncontroversial within the FTC itself.

The FTC hesitates to order corrective advertising injunctions because the effectiveness of such orders is subject to much debate. Several studies indicate that corrective advertising injunctions do not fully undeceive consumers. ${ }^{46}$ In fact, the remedy imposed in the Listerine case apparently failed to correct effectively consumer misperceptions. ${ }^{47}$ Federal courts who adopt a corrective advertising rationale should not confuse the Warner-Lambert court's endorsement of the FTC's power to order a corrective advertising injunction with the conclusion that the injunction itself is an effective remedy. The FTC's infrequent use of corrective advertising injunctions, coupled with studies critical of their effectiveness, indicate that federal courts adopting the theory have been over-enthusiastic in their analysis.

One can criticize corrective advertising damage awards in two ways that go beyond pointing out the federal courts' misperception of the FTC's corrective advertising injunctive remedy. First, the damage awards may be unjustified under existing tort damage law. Second, even if justified by precedent, the damage awards are an economically inefficient and socially undesirable remedy. Part II examines the corrective advertising damage rationale under existing law, and Part III explores the economic implications of corrective advertising damage awards.

14562 F.2d at 762, citing Jacob Siegel Co. v. F.T.C., 327 U.S. 608, 612-13 (1946) (emphasis added).

${ }^{45}$ In Big $O$, the Tenth Circuit apparently accepted the plaintiff's argument that "the Federal Trade Commission often requires businesses who engage in misleading advertising to spend 25 percent of their advertising budget on corrective advertising." $561 \mathrm{~F} .2 \mathrm{~d}$ at 1375. The court was apparently unaware of the fact that the FTC only very rarely orders corrective advertising. Dee Pridgen, Consumer Protection and the Law § 12.07(3)(d) (1986).

${ }^{16}$ Richard Craswell, Interpreting Deceptive Advertising, 65 B.U.L.Rev. 657, 688-89 (1985), citing Robert F. Dyer and Phillip G. Kuehl, A Longitudinal Study of Corrective Advertising, 15 J.Market.Res. 39, 46 (1978) and Michael B. Mazis and Janice E. Adkinson, An Experimental Evaluation of a Proposed Corrective Advertising Remedy, 13 J.Market.Res. 178 (1976).

47 Pridgen, Consumer Protection at $\$ 12.07(3)(d)$ (cited in note 45). 


\section{Damage to Good Will and the Inadequacy of the Corrective Advertising Damage Award}

One startling aspect of the cases discussed in Part $I$ is the courts' willingness to depart from the traditional rule that "any award based on plaintiff's damages requires some showing of actual loss [based on] adequate record support for the dollar amount." ${ }^{48}$ Courts generally do not permit speculative damages; plaintiffs carry the burden of proving not only the fact of damage, but also the amount. An absolutely precise calculation is not required, but damages cannot be computed on "speculation and guesswork."49

When a plaintiff cannot introduce direct evidence of lost sales, the court might bar plaintiff's recovery because the court might regard the plaintiff's damage claim as the result of "speculation and guesswork." Sometimes, in unfair competition cases, the defendant's infringement clearly has caused actual damage to the plaintiff, although that damage may be difficult to pinpoint. Courts have recognized that lost sales and profits are not the only type of damage which result from unfair competition; often the infringement damages a business' or product's good will ${ }^{50}$ as embodied in its trademark. Corrective advertising damage awards are a response to the compensation problems arising in the unfair competition context. They have two possible justifications. First, they may be based on the FTC's repair of consumer perception rationale. Second, they may be explained as an attempt to quantify damages to good will in the absence of direct evidence of lost sales. The first justification explains attempts to measure the cost of actual repair, while the second explains attempts to measure recovery for actual loss.

\section{A. Reputation Repair}

The first justification for corrective advertising damage awards emphasizes the need to restore the plaintiff's reputation to its for-

48 Foxtrap, 671 F.2d at 642. See also St. Charles Mfg. Co. v. Mercer, 737 F.2d at 893; McCarthy, 2 Trademarks at 509-11 (cited in note 1).

49 Bigelow v. RKO Radio Pictures, 327 U.S. 251, 264 (1946) (antitrust damages).

so "Good will" is the value of the association consumers make between a product or business and its trademark. For example, the total value of all the tangible assets (factory, inventory, patents, and trade secrets) of the maker of Oreo cookies might be $\$ 10$ million; yet, a purchaser would be willing to pay much more than this amount for all the assets and the right to use the Oreo trademark because of the valuable associations built up between the cookie and its name. The difference in value between the tangible assets and purchase price is a rough measure of good will. 
mer level via an actual reparative advertising campaign. ${ }^{51}$ It seeks to enable the plaintiff to undo the harm done to its reputation by providing the funds to perform affirmative advertising. Courts have endorsed the compensability of actual advertising on several occasions, ${ }^{52}$ and it seems a small leap to apply the rationale to future reparative advertising expenditures. However, the repair rationale ignores the basic rule of damages that a victim is compensated to mitigate the loss he has suffered, and not for an amount which necessarily will restore his property to its original condition, although the two figures are often the same. ${ }^{53}$

When cost of repair and lost value are not the same, the court will award the lower figure. For example, a car accident results in a dented door which can be repaired for $\$ 150$. Although the lost value caused by the dent may be $\$ 300$, the court will award the plaintiff only the $\$ 150$ necessary to repair the dent. ${ }^{.4}$ Conversely, if the cost of repair is larger than the value lost to the victim, the court will not award damages to enable the repair to take place. If a semi-trailer negligently crashes into and destroys a car worth $\$ 500$, tort law measures the victim's damages at $\$ 500$. In this case, the measure of damages should not be the amount necessary to repair the destroyed car which, depending on its condition, may be many thousands of dollars. ${ }^{65}$ It would be grossly inefficient to give the victim a huge windfall by granting him an award many times the value of his loss.

The car accident example exposes the faulty reasoning of corrective advertising courts: the amount needed to repair a trademark's reputation does not necessarily provide for efficient mitigation of damages. Big $O$ is a good example. At the time of trial, Big $O$ 's total operation, including its trademark and attendant good will, was worth only $\$ 200,000 .^{\mathrm{b}}$ It seems unlikely that it actually

${ }^{31}$ See Big O, 408 F.Supp. at 1232.

${ }^{62}$ See cases cited in note 20 .

${ }^{83}$ See Richard A. Posner, Economic Analysis of Law 108-09 (3d ed. 1986) (discussing efficient damages in contract breach cases).

54 It seems counter-intuitive that the expenditure of $\$ 150$ to repair the dent will restore $\$ 300$ to the car's value. Yet, in some markets, the ratio of improvement expenditures to value is not 1:1. For example, sometimes a $\$ 500$ coat of paint on an old house will increase its market value $\$ 2000$. That significant arbitraging in such markets does not occur may perhaps be explained by the cost of information or high transaction costs.

${ }^{s 5}$ One can make an argument that the victim's subjective value of having the car repaired rather than replaced may sometimes make a seemingly wasteful repair efficient. See Timothy J. Muris, Cost of Completion or Diminution in Market Value: The Relevance of Subjective Value, $12 \mathrm{~J}$. Legal Stud. 379 (1983).

so Big 0, 561 F.2d at 1367. 
sustained a loss of $\$ 2.8$ million, although in reality it might cost that much to restore consumer perception of the "BIG FOOT" trademark to its pre-infringement state. If it costs $\$ 2.8$ million to "fix" the trademark, then, as with the totaled car, it is simply not efficient to do so. ${ }^{57}$ On the other hand, the court in Jartran awarded U-Haul $\$ 12$ million based on the infringer's advertising expenditures. U-Haul is a huge multinational corporation. It is entirely possible that it lost substantially more than $\$ 12$ million in damage to its good will. ${ }^{58}$ Clearly, the propriety of granting damages on the theory that they are necessary to "repair" a trademark or restore its good will value cannot be justified under traditional tort damage principles.

\section{B. Compensation for Damage to Good Will}

Money awards based on the defendant's advertising budget may also be justified as a crude attempt to measure damage to good will. Some courts have recognized that even absent evidence of lost profits, damage to good will should be compensated. Such awards are somewhat controversial given the traditional rule that plaintiffs must prove actual damages. However, if read closely the decisions reveal a judicial acknowledgement that actual damage has occurred to the plaintiff, and the accounting awarded is simply an estimate of the loss, otherwise difficult to calculate, to the plaintiff's good will. Corrective advertising damage awards may be a similar attempt to estimate lost good will.

For example, in Maier Brewing Company v. Fleischmann Distilling Corp., ${ }^{59}$ the Ninth Circuit found that the defendant's use of the name "Black and White" for beer infringed on the plaintiff"s registered trademark of "Black and White" for Scotch whiskey. The plaintiff could not prove diversion of sales and consequent lost profits because the products did not compete with each other. The court offered a dual rationale for the award requiring an accounting of defendant's profits. First, the court recognized that the defendant had injured the product's good will even absent any direct competition or lost sales. Second, the court recognized that al-

${ }^{67}$ This point is related to the idea that the defense of wasteful actual corrective advertising should be available when courts wish to award damages based on counter-advertising performed by the plaintiff. Sometimes actual reparative expenditures may be inefficient. See note 24 and accompanying text.

BB In 1979-80, U-Haul's annual gross revenues were approximately $\$ 400$ million. U-Haul Intern., Inc. v. Jartran, Inc., 522 F.Supp. 1238, 1241 (D. Ariz. 1981).

so 390 F.2d 117 (9th Cir. 1968). 
lowing injury to good will to remain uncompensated, would result in underdeterrence of unfair competition. ${ }^{60}$

Maier stands for the proposition that once injury has occurred, the amount of injury must be estimated in order to achieve an optimal level of deterrence. Presumably, if no damage to good will occurred, the court would award no money. ${ }^{61}$ The Maier court estimated that the defendant's profits roughly approximated the value of the plaintiff's lost good will. ${ }^{62}$ It is hardly clear that the amount of defendant's profits is an accurate estimate of lost good will, but the court was determined to find some way to compensate what it felt was a tangible, if difficult to estimate, loss.

Corrective advertising damage awards may be viewed as a parallel attempt to quantify real damage to good will. However, awards based on the defendant's advertising expenditures seem to be arbitrary and unrelated to damage to good will. For example, although evidence showed that some customers thought unfavorably of the Big $\mathrm{O}$ dealers because they appeared to be palming off their bias-ply tires as Goodyear radials, the fact that the Goodyear product was more expensive and of higher quality may have actually improved the marketability of the Big $\mathrm{O}$ product. In fact, the court's recognition that there was no proof of lost sales and that there was an increase in the number of dealers seems to support the hypothesis that Big O's reputation may have benefited from the infringement. ${ }^{63}$ Good will is a quantifiable asset of a business; no evidence was submitted which proved its value had diminished. Even if Big O had suffered lost good will, the court's valuation of the loss via Goodyear's advertising expenditures seems insupportable. The total net worth of Big $\mathrm{O}$ at the time of trial was $\$ 200,000 .^{64}$ As a measure of damage to good will, $\$ 2.8$ million seems arbitrary.

Similarly, the courts in Jartran, West Bank, and other corrective advertising cases do little more than presume the existence of harm to good will and award defendant's advertising costs as a measure of the supposed harm. This is not to say that no harm to good will occurred in these cases, or that harm to good will and reputation should not be compensable; but these cases do illustrate the arbitrariness of basing an award on a proxy for, rather than a

\footnotetext{
${ }^{60}$ Id. at 122-123.

-1 For example, because the infringing product was of high quality.

62390 F.2d at 123.

os See text accompanying note 28 .

os 561 F.2d at 1367 .
} 
direct evaluation of, damage to good will. ${ }^{65}$

One might level this same criticism, of course, at the remedy of an accounting. The Maier court, for example, performed no direct calculation of loss to good will. In this sense, corrective advertising damages do seem to have a basis in at least one line of tort damage law. Thus, the strongest criticism of a corrective advertising damage award is not that it is unprecedented, but that it is unresponsive to the efficiency goals underlying tort damage law itself. $^{66}$

\section{Economics and the Importance of Accurate Measure- MENT of Damage to Good WILL}

Corrective advertising damages seek to compensate defendants for tangible losses to trademark good will. The justification for awarding damages based on the defendant's advertising budget assumes that unfair competition may damage reputation even absent direct evidence of lost profits. This section discusses what reputational damages are optimal in the unfair competition context, and whether corrective advertising substantially approximates those damages. ${ }^{67}$

A corrective advertising award primarily seeks to address damage to good will, which, in the cases discussed in this comment, is substantially the same as damage done to trademark reputation. A trademark merely embodies good will, as Professor McCarthy explains:

${ }^{65}$ In fact, some courts have rejected claims for monetary awards based on corrective advertising because the plaintiff has not met the evidentiary burdens normally imposed by tort law. In Mercer, 737 F.2d 891, a kitchen cabinetmaker sued the developers of a townhome community who misrepresented that their townhomes would contain the plaintiff's cabinets when in reality they did not. The court granted the cabinetmaker an injunction but refused to award damages "to 'reverse advertise' to overcome any damage to their reputations that defendants' actions might have caused." Id. at 893 . The court refused to award damages because "plaintiffs introduced no evidence showing any damage to their reputations." Id.

Similarly, in Engineered Mechanical Serv. v. Applied Mech. Tech., Inc., 591 F.Supp. 962 (M.D.La. 1984), the court held that damages for corrective advertising would not be awarded where "the plaintiffs have presented no evidence on loss of good will, damage to their reputation, the need for corrective advertising and no evidence of any numerical values on which such an estimate could be based." Id. at 966 .

${ }^{B B}$ These efficiency goals are recognized in Maier when the court speaks of the need to deter the defendant's behavior through the award of an accounting. 390 F.2d at 122-123. Part III explores whether corrective advertising provides optimal deterrence.

${ }_{67}$ This comment relies primarily on the descriptive economic tort theories contained in William M. Landes and Richard A. Posner, The Economic Structure of Tort Law (1986) Posner, Economic Analysis of Law (cited in note 53); and William Landes and Richard Posner, Trademarks: An Economic Model (forthcoming). 
Good will and its symbol, a trademark, are inseparable. A trademark has no independent significance apart from the good will it symbolizes. If there is no business and no good will, a trademark symbolizes nothing. ${ }^{68}$

A trademark has value because consumers associate a certain level of product quality with it; a trademark also makes the product easier to remember and find. The connection the consumer makes between a trademark and a product is crucial to a product's success. If Coca-Cola changed its name to "Fizzy Cola," it would experience a substantial decline in sales, even if the beverage's ingredients remained unchanged. The plummeting sales would indicate loss of the good will that the company had built through decades of successful promotion of the name Coca-Cola. When consumers' ability to associate products and their trademarks is hampered, a very real financial loss of good will results.

\section{A. Optimal Deterrence of Damage to Good Will}

Tort law attempts to provide optimal deterrence of opportunistic behavior by forcing the tortfeasor to internalize the social cost of his actions. Forcing him to pay too much encourages him to take more care than is efficient; forcing him to pay too little encourages him to take less care than is efficient. However, before addressing the evils of miscompensation, this comment will discuss some preliminary points about the optimal level of damages for lost good will and whether corrective advertising awards approximate that level.

1. Accuracy of Compensatory Damages. The primary problem with corrective advertising damage awards is that the defendant's advertising expenditures are arbitrary and, depending on the particular fact situation, provide a figure which may be substantially more or less than the actual damage to good will. Big $O$ offers a good example of plaintiff overcompensation. ${ }^{69}$ One might also imagine a damage award based on the defendant's advertising costs that would undercompensate a plaintiff. For example, a rival of McDonald's might spend a mere $\$ 100$ to print up leaflets accusing McDonald's of using worm meat in its hamburgers. Harm to McDonald's reputation might be substantial, yet an award based on advertising costs would not exceed $\$ 100$. Under the traditional economic model, all actual damages are calculated and then adjusted

${ }^{88}$ McCarthy, 1 Trademarks at 76 (cited in note 1).

89 See text at notes 26-29, 63-64. 
to take into account the possibility that the tortfeasor might not be caught. The size of the defendant's advertising budget is irrelevant. ${ }^{70}$ The arbitrary nature of corrective advertising awards and their lack of consistent relation to actual damages powerfully demonstrates their inefficiency.

Another observation indicates that corrective advertising damage awards may consistently result in overcompensation. Corrective advertising awards non-incremental damages: the court awards the plaintiff all of his damages, not just those caused by the unfair competition. Non-incremental damages result in overcompensation. ${ }^{71}$ For example, McDonald's sells a roast beef sandwich; Burger King sells a similar sandwich with a similar name. If damages for lost profits are granted, Burger King will have to disgorge all of its profits, including those it would have made anyway had it given its product a totally different name. McDonald's will have recovered all of Burger King's profits even though only some were due to customer confusion. Burger King would have earned most of the profits anyway-taken from undeceived Burger King customers who decided they wanted a roast beef sandwich instead of a hamburger. An incremental measure of damages would award McDonald's only the amount of damage caused by the customer confusion, not the entire amount earned by Burger King. One achieves optimal deterrence only when the incremental damage amount is awarded.

A final reason to suspect that corrective advertising damages overcompensate plaintiffs is that the cost to defendants of the injunctive relief granted is not subtracted from the award. When the sum awarded to the plaintiff is that necessary to compensate him fully for his actual damages, the court should not take the cost of an injunction into account. However, when courts increase the award beyond mere compensation in order to increase deterrence, the cost of the injunction properly is considered.

For example, if a court determined a plaintiff's loss was $\$ 1$ million, and that a total cost of $\$ 2$ million should be imposed on the defendant to deter him and others in the future, it should order the defendant to pay the plaintiff $\$ 1$ million. The remaining $\$ 1$ million penalty which the defendant must incur should be reduced

70 Actually, advertising budget size and the risk of apprehension may be inversely related. The larger the defendant's advertising budget, the greater the chance of apprehension; therefore, damages arguably should be diminished in some situations.

${ }^{71}$ Richard Craswell and John E. Calfee, Deterrence and Uncertain Legal Standards, 2 J.L.Econ. \& Org. 279, 297 (1986). 
by the cost of the injunction. If the injunction alone imposed more than $\$ 1$ million in costs on the defendant, no further transfer payments to the plaintiff are necessary.

Injunctions are costly. It is expensive to change the name of a product line; the injunction may render some manufactured products completely unsalable. Although courts often deny damages because a preliminary injunction seems sufficient punishment, ${ }^{22}$ courts generally do not subtract the cost of an injunction once they award increased damages. This results in higher than optimal damages even if corrective advertising monetary awards are otherwise proper.

In response to the criticisms above, one might offer some defenses of corrective advertising damage awards. At least one commentator has argued that if a particular legal rule is absolutely clear and certain, courts can award damages at immense levels without fear of overdeterrence because all actors will stay just to the compliance side of the liability line without fear of incurring any loss. ${ }^{73}$ It is difficult to argue that overcompensation is bad in this clear rule scenario because increasing the size of the award does not affect the level of care: actors will not back further away from the liability line.

Given this theory, one can argue that corrective advertising damage awards are like harmlessly increased damages for the violation of a clear legal rule. However, there exist three responses to this argument. First, there is no indication that legal rules are certain in cases where courts have awarded corrective advertising damages. For example, in Big $O$ the only legal precedent on point indicated that the sort of reverse confusion caused by Goodyear was not actionable, but the court, nevertheless, awarded huge damages. ${ }^{74}$ Second, if corrective advertising is a smokescreen for increased damages, courts should stop claiming a compensation rationale and articulate why punitive damages are appropriate. Finally, there is no reason to believe that corrective advertising damage awards result from a rational analysis of any actual harm to plaintiffs. Courts neither quantify actual harm nor explain any logical relationship between advertising expenditures and the need to deter the defendant's conduct in a particular case.

2. Imperfect Enforcement. Because no law is perfectly en-

72 See Champion Plug Co. v. Sanders, 331 U.S. 125, 131 (1947).

${ }^{33}$ Robert Cooter, Prices and Sanctions, 84 Colum.L.Rev. 1523 (1984).

74561 F.2d at 1371, citing Westward Coach Manufacturing Co. v. Ford Motor Co., 388 F.2d 627 (7th Cir. 1968) (applying Indiana law). 
forced, corrective advertising damages may be an attempt to provide efficient deterrence by increasing awards to compensate for the chance that the tortfeasor may not face suit. If a tortfeasor knows that he will not always be caught, forcing him merely to compensate the plaintiff for the damage done when he is caught will not deter him from acting illegally again.

Conventional economic analysis of damages takes into account the teaching that "the optimum penalty is simply the social cost of the unlawful act divided by the desired probability that the penalty will in fact be imposed."7s In unfair competition cases, courts traditionally have required the defendant to compensate the plaintiff for all of the plaintiff's losses including lost profits, damage to good will, and other infringement related expenses. In theory, this level of damages might not provide incentives for the tortfeasor to take an efficient level of care because courts normally do not increase damages in variation with the tortfeasor's probability of apprehension. Perhaps the large damage awards sometimes provided by corrective advertising are judicial attempts to achieve optimal deterrence by considering the likelihood that an infringer will get away with his misdeed. However, one can offer several criticisms of this explanation. First, it is difficult to hide an act of trademark infringement. By its nature, a trademark has a conspicuous public presence; the chances of infringement escaping detection are low. Therefore, any increase in actual damages should be relatively minor. Certainly an award many times the possible actual harm, as was granted in Big $O$, seems unjustified.

Second, courts may be considering imperfect enforcement silently and multiplying total damages by one over the chance of apprehension. If so, then they are using the wrong number as a multiplicand. In order to arrive at the damage figure providing for optimal deterrence, one should multiply one over the chance of apprehension by the amount of incremental damages, not the amount of total damages. ${ }^{76}$ If one uses the amount of total damages, defendants will be deterred from causing any loss to the plaintiff, while optimally one only wants to deter a defendant from imposing losses which are illegal for him to cause. By using the plaintiff's total losses as the multiplicand, the corrective advertising courts are compounding the problem of non-incremental damages, discussed above in subsection one. Even taking into account the need

${ }^{75}$ Richard A. Posner, Economic Analysis of Law 171 (2d ed. 1977) (speaking of deterrence in the criminal law context).

${ }^{78}$ Craswell and Calfee, 2 J.L.Econ. \& Org. at 292-297 (cited in note 71). 
to increase damages in response to imperfect enforcement, corrective advertising damages still miscompensate.

3. Uncertain Legal Standards. Traditional damage theory may not completely explain all of the elements of optimal deterrence. Recent scholarship indicates that a given level of damages may result in overcompensation or undercompensation depending on the clarity of the relevant legal rules. ${ }^{77}$

Taking the likelihood of the defendant facing suit into account, as discussed in subsection two above, provides for efficient deterrence only if the probability of punishment is constant. If the tortfeasor knows that his chance of getting caught is one out of three, a court confidently can triple the incremental damages done to the victim in order to provide optimal deterrence. But what if the legal rule governing the tortfeasor's actions is unclear? To determine optimal damages, a court must evaluate the chance of apprehension not only in light of the probability of the broken rule's enforcement, but also with reference to the certainty with which the defendant knew he was breaking the legal rule. Corrective advertising damages may be justifiable, perhaps, given the degree of legal uncertainty in the field of unfair competition.

Knowledge of the relative clarity of legal rules governing unfair competition would allow a more perfect critique of corrective advertising damage awards. The clarity of legal rules directly affects actors attempting to conform to a legal standard. The predictability of application of legal rules has important ramifications for all tort law because it calls into question the traditional assumption that compensatory damages provide incentives for optimal deterrence. Two commentators explain:

Uncertainty creates a positive chance that someone who violates the legal standard will not be punished, thus reducing the incentives to comply [underdeterrence] . . . . However, uncertainty often allows an actor to reduce the probability of punishment even further by "playing it safe" and modifying his behavior by more than the law requires [overdeterrence]. ${ }^{78}$

Therefore, the level of damages necessary to provide optimal deterrence depends upon the uncertainty of the underlying legal rule. In general, given a fixed level of damages, relatively small uncertainty will lead to overdeterrence and broad uncertainty will lead

${ }^{78}$ Id. at $279-80$. 
to underdeterrence. ${ }^{79}$

Unfortunately, even if one could quantify the clarity of substantive legal rules governing unfair competition, such a task is beyond the scope of this comment. However, even without pinpointing the exact level of uncertainty, it seems that corrective advertising damages cannot be justified within the uncertain legal standard framework. First, it seems unlikely that an arbitrary compensation scheme like corrective advertising could provide proper incentives because of the inconsistency inherent in such a rule. Arbitrariness leads to over- or underdeterrence, even if we do not know the degree of legal uncertainty. ${ }^{80}$

Second, the non-incremental nature of corrective advertising damages suggests that overcompensation occurs even without an exact quantification of legal certainty. The damage awards in the cases discussed in this comment seem to be substantially in excess of actual loss to the tort victim. Professors Craswell and Calfee have calculated optimal multipliers given varying degrees of legal uncertainty and concluded that the proper number by which to multiply the total social cost of the tort typically is not much larger than one. ${ }^{81}$ This indicates that even given a wide range of uncertainty, corrective advertising damages overcompensate. Corrective advertising damages therefore are not justifiable as implicit adjustments for the uncertainty of legal standards governing unfair competition.

\section{B. Effects of Miscompensation}

When a manufacturer markets an infringing product, it may be liable for damages caused by the infringement. Because of this possibility, a manufacturer must take care before it markets a new product to search for existing trademarks, trade dress, or product configurations which its product may infringe. If courts consistently award plaintiffs higher than optimal damages for infringement, the manufacturer must take increased care in order to lessen potential liability for infringement. ${ }^{82}$ If courts consistently award less than optimal damages, a manufacturer will take less care because it faces a decreased risk of loss. Overcompensation and overdeterrence result in fewer and costlier new products; un-

${ }^{29}$ Id. at 280.

so However, if the rule was absolutely clear, an arbitrary award over a compensatory level would be efficient.

sx Craswell and Calfee, 2 J.L.Econ. \& Org. at 294 and table 8 (cited in note 71).

82 See Landes and Posner, Trademarks (cited in note 67), 
dercompensation and underdeterrence result in more infringement creating consumer confusion, higher consumer search costs, and fewer incentives to market high quality goods. ${ }^{83}$

1. Overcompensation. Overcompensation results in three main evils. First, manufacturers will introduce fewer new products, especially cheaper products which may exploit markets created by preexisting goods, because of the increased risk of damages. Manufacturers will not be willing to market goods which bear a close resemblance to those already on the market. They will hesitate to provide consumers with cheap copies of products in high demand because such marketing behavior sometimes results in lawsuits.

However, merely because product copying sometimes is illegal does not justify overdeterring all copying. One must remember that all copying is not infringement. Copying of products, excluding their trademarks, is completely permissible absent a patent. ${ }^{\mathbf{3 4}}$ Although some Lanham Act decisions have recognized that products can act as their own trademarks and therefore can obtain some protection from copying, ${ }^{85}$ in general, copying of unpatented objects is permitted. This policy stimulates competition and results in cheaper products being made available to the consumer. Higher damage awards decrease the likelihood that a manufacturer will market a possibly infringing product. As a result, some noninfringing products will not be produced because of the enhanced risk. ${ }^{86}$ This results in fewer product choices for consumers and less price-lowering competition.

Second, fear of inordinately high damage awards increases marketing research costs. One must take excessive care when overly high risk has been created. A regime of huge damage awards for infringement forces manufacturers to spend large amounts for trademark searches and legal opinions regarding infringement. These costs are passed on to consumers in the product's price.

Finally, high damage awards not only affect cases which go to trial, they also affect settlement negotiations. A legal rule allowing exorbitant damages provides plaintiffs with extra leverage when settlement talks begin. Although a plaintiff's case may be weak, fear of excessive damages may cause the defendant to settle for an

83 Id.

84 See, for example, Sears Roebuck \& Co. v. Stiffel Co., 376 U.S. 225, 231 (1963) (Court held that federal patent law preempted much common law protection of unpatented product configurations).

${ }^{85}$ See, for example, LeSportsac, Inc. v. K Mart Corp., 754 F.2d 71, 75 (2d Cir. 1985).

${ }^{86}$ This is subject, of course, to the certainty of the legal rules governing infringement. Since this section assumes miscompensation, the legal uncertainty variable will be ignored. 
inefficient amount rather than risk trial. This possibility compounds an inefficient damage measure's distorting effect on the market.

2. Undercompensation. Undercompensation is equally inefficient. When courts undercompensate plaintiffs, courts do not deter manufacturers from marketing infringing products. Three main problems result from increased infringement. First, consumer confusion results. Consumers frequently may buy one product thinking it is another. Purchasing errors are costly and result in wasted resources.

Second, consumer difficulty in differentiating between infringing products and the products they desire raises consumer search costs. Consumers must spend more time finding exactly the product they desire when the convenient mnemonic device of the trademark is untrustworthy.

Third, undercompensation resulting in increased infringement lowers manufacturers' incentive to market high quality goods. Since high quality goods are expensive to manufacture, consumer association of quality with the product name is particularly important. Production of cheap imitations bearing names which deceive consumers weakens the connection between the name and quality of the original high quality good. Eventually, a manufacturer has no incentive to spend the extra money to produce high quality goods because it will be unable to make a profit-too many consumers will buy what they think are the manufacturer's high quality goods at the lower price charged by the infringer. Clearly, undercompensation is as great a vice as overcompensation.

\section{Necessity of Direct Valuation of Damage to Good Will}

Tort law seeks to minimize social costs through optimal deterrence. The optimal level of compensation balances the need to deter the marketing of confusing products and the need to encourage low cost product development and competition. In determining the optimal sanction to impose one must first calculate as precisely as possible the victim's actual damages. All methods of fixing damages involve awarding damages equal either to actual damages or to actual damages multiplied by some variable. Because corrective advertising damages do not provide an accurate measure of damage to good will, courts must use a more accurate method. Accounting procedures which measure good will may offer far more precise estimates of actual damage than arbitrary awards of corrective advertising.

Although no trademark infringement decisions detail how loss 
to good will should be calculated, ${ }^{87}$ cases in antitrust, ${ }^{88}$ condemnation, ${ }^{80}$ marital dissolution, ${ }^{80}$ probate, ${ }^{91}$ partnership,,${ }^{92}$ tax, ${ }^{93}$ and tort $^{94}$ demonstrate judicial willingness to set a dollar value on good will. Formulas tailored to the needs of these varying fact situations have been developed to measure good will. ${ }^{95}$ Courts can adopt one of these formulas to determine damages to good will in unfair competition actions.

\section{A. Warning and Encouragement}

Before examining specific approaches, several important points should be noted. The examples which follow are paradigms; they do not purport to set rules which govern the whole panoply of variations on the unfair competition theme. Rather, they merely illustrate the possibility of accurately calculating good will losses. Due to the specificity required in valuing good will, some caveats regarding the speculative nature of these general examples are discussed in subsection one below.

1. Variables and Multipliers. All of the examples below use the same multipliers and variables. However, intuition tells one that rates of return for different types of assets are not identical, nor should all capitalization occur at the same rate. In an actual

${ }^{87}$ Century Distilling Co. v. Continental Distilling Corp., 86 F.Supp. 503, 505 (E.D.Pa. 1949), aff'd 205 F.2d 140 (3d Cir. 1953) (expert witnesses allowed to calculate good will value; but methodologies were not discussed).

${ }^{83}$ Standard Oil Company of California v. Moore, 251 F.2d 188, 219-20 (9th Cir. 1957).

89 Kimball Laundry Co. v. U.S., 338 U.S. 1 (1949).

90 Mueller v. Mueller, 144 Cal.App.2d 245, 301 P.2d 90, 94-5 (1956).

91 Copland v. Wisconsin Department of Taxation, 16 Wis.2d 543, 114 N.W.2d 858, 86467 (1962).

${ }^{22}$ Lyon v. Lyon, 54 Cal.Rptr. 829, 246 Cal.App.2d 519 (1966); Murray v. Bateman, 315 Mass. 113, 51 N.E.2d 954 (1943).

${ }^{23}$ Courier Journal Job Printing Co. v. Glenn, 37 F.Supp. 55, 59-60 (W.D.Ky. 1941), aff'd 127 F.2d 820 (6th Cir. 1942).

or Carrey v. Boyes Hot Springs Resort, Inc., 54 Cal.Rptr. 199, 245 Cal.App.2d 618, 62223 (1966).

${ }^{\text {os }}$ Edward J. Schnee, Acquiring Assets by Purchasing Corporate Stock, 13 Tax Adviser 354, 361-63 (1982) (valuation for tax considerations); Comment, Professional Goodwill in Louisiana: An Analysis of its Classification, Valuation, and Partition, 43 La.L.Rev. 119 (1982) (valuation in marital dissolution setting); Patricia K. Ganier, Treatment of Good Will: Allocating a Lump-Sum Purchase Price Among Mixed Assets of a Going Business, 7 J.Corp.Tax 111 (1980) (valuation for sale purposes); Gregory M. Bergman, The Valuation of Goodwill, L.A.Bar J. 87 (Aug. 1977) (discussion of methods used by California courts); Note, Valuation of Good Will for Tax Purposes, 48 Va.L.Rev. 1274 (1962); Note, An Inquiry into the Nature of Goodwill, 53 Colum.L.Rev. 660 (1953); Forensic Economics-Valuation of Business and Business Losses, 16 Am.Jur. Proof of Facts 2d 253, 375-84 (1978) (valuation of good will of professional practice, Good Will, 5 Am.Jur. Proof of Facts 505 (1960). 
unfair competition case, the rate of return on tangible assets may be more accurately determined by reference to the average rate of return for similar businesses or professions rather than by the rate fixed by the IRS. Similarly, the capitalization rate employed will depend on the type of business, and the suggested period over which capitalization is calculated will vary with the stability of the particular business. By applying current procedures and developing new ones, accountants and other experts should be able to adjust for these variables and refine the science of good will damage calculation considerably.

2. Advertising and Profitability. Several studies have provided information about the relation between the value of advertising over time on the one hand and profitability on the other.$^{96}$ Further development in this area may improve estimates of good will's capitalization period. These studies should also result in more accurate calculations of the extent of damage done by false advertising and trademark infringement.

3. New Businesses and Products. Determining the good will damage to relatively new businesses or products presents particularly difficult problems. Courts historically have refused to speculate on the profits a new business might have earned. Calculating the good will of a new business is no less speculative. As in other damage contexts, courts must determine the possibility of calculating the good will of a new business or product on an individual basis.

Overall, because they seek to value good will directly, accounting techniques provide more accurate measurements and, therefore, if utilized, will produce damage awards which deter infringement more efficiently than do awards based on corrective advertising. Even so, room for improvement exists and improvement will certainly come to pass as increasingly complex responses to the valuation problem develop.

\section{B. Calculating Good Will Loss of a Business}

"Yummy Foods" is a well-established and prosperous supermarket. Hoping to capitalize on Yummy Foods' reputation for providing high quality goods and services, a local entrepreneur opens a small convenience store called "Yum E. Treats" in the same town as Yummy Foods. Yum E. Treats sells a small variety of low

${ }^{86}$ See, e.g., Meryl Paula Gardner, Advertising Effects on Attributes Recalled and Criteria Used for Brand Evaluations, 10 J.Cons.Res. 310-18 (1985). 
quality foodstuffs, trinkets, and tasteless magazines (products not sold by Yummy Foods). Given a finding of infringement under the Lanham Act and common law, Yummy Foods is entitled to an injunction as well as any lost profits and actual damages it can prove. Upset by the numerous complaints Yummy Foods has received about the low quality and offensive nature of some of Yum E. Treats' inventory, Yummy Foods suspects that its reputation has been damaged. However, it has no proof of any lost sales. In fact, Yummy Foods has lost no sales directly to Yum E. Treats because the store was located on the opposite side of town and may have diverted business only from other convenience stores in the vicinity.

A business which suspects damage to its good will may use several accounting techniques to measure its loss, if any. All involve a differential comparison of the good will value of the business before and after the infringement. ${ }^{97}$ One simple measure of the good will value of a business is the difference in the value of the business' tangible assets, such as buildings and inventory, and the appraisal value of the business as a whole. ${ }^{98}$ The difference between the value of the assets and the appraisal value of the business before and after the infringement then represents the damage to good will. Of course, appraisal value may be highly subjective, generating expert witness problems seen in other valuation contexts. However, appraisal would be more reliable if the courts required the value to be tied to a concrete pre-infringement offer for the business or product line or, more conveniently, to a comparison of rates of return on capital invested in the same market.99

The IRS frequently employs the above method, the "gap the-

${ }^{97}$ All of these techniques also involve a measurement of the business' revenue flow. Therefore, the value of good will tends to vary directly with profits, although it need not, since a profitless company may still have substantial good will in its name (i.e., under a different name it might have lost even more money).

98 Ganier, 7 J.Corp.Tax at 121 (cited in note 95).

'o See Bloor v. Falstaff Brewing Corp., 601 F.2d 609, 615 (2d Cir. 1979) (contract damages based on profits made by similar brands of beer sold in the same market). For example, if the plaintiff were a beer distributor, one would determine a typical rate of return on capital invested in similarly situated distributorships. If the plaintiff earned an average of 3 percent above the typical rate before infringement and during the infringement it only earned 2 percent below the typical rate, the 5 percent net drop in relation to the norm might be attributable to the infringement. The comparison to similarly situated businesses allows damages to be adjusted in spite of fluctuations affecting the entire market. Even if a plaintiff's rate of return may have increased as compared to its previous performance, it may be less productive in relation to its market peers who may have experienced an even greater growth. This is evidence of lost good will which may be attributable to infringement. 
ory."100 It works well when tangible assets and appraisal value are easily determinable; however, business conditions may make appraisal value uncertain. ${ }^{101}$ Another approach responds to this difficulty by using a business' annual earnings, rather than an expert's appraisal value, to calculate the value of the entire business. ${ }^{102}$ The value of tangible assets is then subtracted and whatever remains represents good will. More specifically, this approach employs the following steps to determine good will:

(1) Compute the average annual earnings of the firm for a period of not less than five years immediately preceding the valuation date;

(2) Compute the average annual value of the tangible. assets for the firm for the same period;

(3) Determine an annual return on the tangible assets by multiplying the value of the tangible assets by a stated rate of return; ${ }^{103}$

(4) Subtract the annual return on tangible assets from the annual average earnings;

(5) Determine the value of good will by capitalizing ${ }^{104}$ the excess return computed in the prior step. ${ }^{105}$

To determine damages, this calculation must be performed twice: once to determine the good will value before the infringement and once to determine its value after the infringement ceases.

For example, if Yummy Foods earned $\$ 1$ million per year for the five years preceding the infringement and the average value of its assets (primarily buildings and inventory) were $\$ 10$ million, one can make the following calculation. Using the IRS suggested rate of return of 8 percent and capitalization rate of 15 percent, the good will value of the business before the infringement is $\$ 1.33$

${ }^{100}$ Ganier, 7 J.Corp.Tax at 123 (cited in note 95).

101 See McCarthy, 1 Trademarks at 84 (cited in note 1).

102 An expert appraiser may use the firm's earnings as a basis for his appraisal, making the two methods converge to a certain degree.

${ }^{103}$ The rate of return on an asset is the ratio of the income that the asset normally generates in a year to the price of the asset.

104 Capitalizing involves a calculation of the amount necessary to generate a certain level of income-basically the reverse of calculating a rate of return. For example, if the rate of capitalization is 10 percent, then the amount of capital necessary to generate $\$ 100,000$ is $\$ 1$ million. However, these figures depend on the length of time over which one capitalizes. The capitalization period in the case of good will is business or product specific because it varies substantially with the fame and reputation of the trademark.

${ }^{103}$ Schnee, 13 Tax Adviser at 361 (cited in note 95). For step (3), the IRS suggests a rate of 8 percent for low risk firms and 10 percent for high risk firms. For step (5) the IRS suggests rates of 15 percent for low risk firms and 20 percent for high risk firms. 
million. ${ }^{106}$ If one performed the calculation again to evaluate the value of good will at the time the infringement ceased, producing a figure of $\$ 1$ million, then the total compensable damages would be $\$ 330,000$.

Both the earnings calculation method and the appraisal value methods are problematic, however. As mentioned earlier, many market variables affect the outcome of these calculations, and appraisal value may be overly subjective and subject to manipulation by experts. And, various causation arguments may reduce or eliminate the damage award because a portion of a business' good will value can be attributed to non-trademark factors, such as location, service, and building quality. ${ }^{107}$ If during the period of infringement other events have occurred that might account for a decrease in the value of good will, such as the opening of a new and better store nearby, an employee strike, or a leaky roof, courts should decrease damages accordingly.

Some fact situations will present complex accounting problems, but such difficulties are not unique to the unfair competition context. Because accounting methods attempt to measure the exact extent of damage to good will, they are preferable to the totally arbitrary figure generated by basing an award on a defendant's advertising expenditures.

\section{Calculating Product Good Will}

Often a business' or corporation's reputation is unharmed when one of its products is infringed. Generally, the good will associated with the infringed product's trademark rather than the company's overall reputation suffers the most damage. One must adapt the methods discussed in subsection $B$ above to measure such damage. Calculations of product good will may be more accurate than calculations of business good will because unlike business good will, which may include such factors as location and service, a particular product's good will is embodied entirely in its trademark. Fewer elements affect the causation question.

For example, Flusho Corporation sells several products, one of

${ }^{108}$ This figure is derived from the computation:

$$
\frac{\$ 1,000,000-(.08 \times \$ 10,000,000)}{.15}
$$

McCarthy notes that the figure obtained also varies with the number of years over which the good will is capitalized. 1 Trademarks at 80-82 (cited in note 1).

${ }^{107}$ Bergman, 53 L.A.Bar J. at 95-96 (cited in note 95). 
which is Humectroid shampoo. A competitor, jealous of Humectroid shampoo's success, markets Humectrin conditioner. If liability is established, Flusho will be entitled to an injunction. However, Flusho will have difficulty in computing lost profits because Humectrin conditioner did not compete directly with Humectroid shampoo. Even so, depending on the quality and success of Humectrin conditioner, the good will of the Humectroid trademark may have been damaged.

Courts can calculate the value of a trademark's good will as the hypothetical loss which would be incurred if one changed the product's name. For example, if BMW changed its name completely, it would sell far fewer cars and would be able to charge less for each one. ${ }^{108}$ Presumably in the future the car's quality would again become known to the public through its new trademark, and sales and profit margin would again be back to normal. The difference in expected net earnings from the time of the cessation of the use of "BMW" until the reassociation of the car with its new trademark represents the monetary value of the good will of the BMW trademark. One could also calculate this same figure by finding the difference between the value of a typical BMW franchise and a hypothetical franchise which sold BMW cars under a different name. Both methods involve the same comparison of appraisal values before and after the infringement as required for the IRS "gap" method. Depending on the product and market, this value will be more or less easy to determine accurately.

With a few adjustments, the second method described in Section $B$ can also be used to determine damages to a product's good will in a more concrete manner. ${ }^{109}$ The formula might be adapted as follows:

(1) Compute the average annual earnings from product sales for a period of not less than five years immediately preceding the valuation date;

(2) Compute the average annual cost of production and marketing;

(3) Determine an annual return on a sum equivalent to the total cost of production and marketing;

(4) Subtract the annual return calculated in step (3) from the average annual earnings;

${ }^{108}$ Assume that it would not be allowed to establish its new name with reference to its old one as did Datsun when it changed to Nissan.

${ }^{109}$ See text accompanying notes 100-105. 
(5) Determine the value of the good will by capitalizing the excess return computed in the prior step.

With this method, one can determine the damage to good will in the Humectroid infringement example above. Assume that Humectroid's average annual sales are $\$ 10$ million and its average annual production and marketing costs are $\$ 9$ million. Using the IRS suggested rate of return of 8 percent and a capitalization rate of 15 percent, Humectroid shampoo's pre-infringement good will value is $\$ 1.83$ million. ${ }^{110}$ If the value of the good will post-infringement was $\$ 1.5$ million, a court would assess damages of $\$ 330,000$.

Again, a variety of factors affect the validity of the $\$ 330,000$ figure. If the FDA had forced Flusho to put a health warning on Humectroid shampoo that significantly affected sales during the time of the infringement, a court should reduce or eliminate damages. Such a factor makes the accounting problem more difficult, but not impossible. Business and product lines are sold every day. Investment bankers, business brokers, and accounting firms frequently value good will for sale purposes. ${ }^{111}$ Expert witnesses or special masters can deal with the interplay of variables. Such aspects of valuing good will are not unique to unfair competition but arise in most tort damage calculations.

\section{CoNClusion}

Courts realize that unfair competition may damage business or product good will despite lack of evidence of lost profits. However, courts have yet to develop a sound rationale for calculating the amount of damage to good will. The arbitrariness of basing a damage award on the advertising budget of an infringer upsets the efficient balance which tort law seeks to establish between overcompensation and undercompensation. Such inefficiency harms both businesses and consumers. The solution is to employ accounting methods which can accurately measure good will, rather than to rely on a proxy such as defendant's advertising expenditures.

Although procedures have not yet been refined to address all of the accounting problems inherent in the unfair competition context, there is no reason to expect that unfair competition damages

110 This figure is derived from the following computation:

$$
\frac{\$ 10,000,000-\$ 9,000,000-(\$ 10,000,000 \times .08)}{.15}
$$

11 For a particularly sophisticated method of business valuation see Alfred Rappaport, Financial Analysis of Mergers and Acquisitions, J.Merg. \& Acq. 18-36 (Win. 1976). 
and accounting methods cannot evolve in much the same way personal injury damages have developed to compensate plaintiffs more precisely for injury. Judges in personal injury cases stemming from auto accidents do not throw up their hands and calculate damages based on the amount the negligent driver spent to buy his car. Judges in unfair competition cases should not ignore traditional tort rules or economic common sense and base damages on the infringer's advertising costs. A more rigorous look at valuing good will is necessary. 